\title{
Dendrodoris arborescens (Collingwood, 1881) (Mollusca: Nudibranchia): larval characteristics reveal a masked porostome species
}

\author{
Gilianne D. Brodie ${ }^{1}$ and Gonçalo Calado ${ }^{2}$ \\ ${ }^{1}$ Institute of Applied Sciences, University of the South Pacific, Suva, FIJI (e-mail: brodie_g@usp.ac.fj). \\ ${ }^{2}$ Centro de Modelação Ecológica IMAR. FCT/UNL Quinta da Torre 2825-114 Monte da Caparica PORTUGAL and \\ Instituto Português de Malacologia. Zoomarine, E.N. 125, km 65. Guia. 8200-864, Albufeira PORTUGAL (e-mail: \\ ipm@zoomarine.pt).
}

\begin{abstract}
The nudibranch Dendrodoris arborescens (Collingwood, 1881) has hitherto been (1) mistaken for the sympatric species D. nigra (Stimpson, 1855), which is similar in appearance; or (2) considered as a colour form of $D$. fumata (Rüppell and Leuckart, 1828). However, our investigations linking larval form, morphology and colour pattern, clearly show that $D$. arborescens is a separate valid species with its own set of unique characteristics. This result increases the number of Dendrodoris species known from Australian to thirteen, highlights the useful nature of larval features to species identification and contributes to the resolution of a previously confusing species complex.
\end{abstract}

\section{INTRODUCTION}

For many years the genus Dendrodoris Ehrenberg 1831 has been the subject of considerable scientific interest. This results from its relatively common occurrence (Valdés et al. 1996; Brodie et al. 1997), internal (de novo) production of toxic chemicals (Cimino et al. 1983; Karuso 1987, Fontana et al., 1999), unique functional biology and microstructure (Klussmann-Kolb and Brodie 1999; Wägele et al. 1999), suctorial feeding method (Young 1969) and intriguing phylogenetic placement (Valdés and Gosliner 1999; Wägele and Willan 2000; WollscheidLengeling et al. 2001; Valdés 2003). Several widespread members of the genus e.g., Dendrodoris nigra (Stimpson 1855) and D. grandiflora Rapp, 1827 are also well known for their considerable colouration variation (see Edmunds 1971; Thompson 1975; Rose 1985; Valdés et al. 1996). In Australia, this latter attribute in $D$. nigra and its sibling species $D$. fumata have masked the existence of a less common but very similar looking sympatric species $D$. arborescens.

Rose (1985) studied in detail the egg masses and embryonic development of "colour variants" of the nudibranch $D$. nigra along the coast of New South Wales. He documented at least two forms that were clearly distinguished by larval morphology. However, no anatomical or morphological investigation of the colour variants was undertaken nor were associated voucher specimens designated, making re-evaluation difficult.

Several years later Brodie et al. (1997) investigated the external morphology and internal anatomy of $D$. nigra and separated it from the sympatric species D. fumata (Rüppell and Leuckart, 1828) on the basis of external appearance (colour pattern, gill structure) and features of the reproductive system (vestibular gland). Three colour forms of $D$. fumata (grey, black and orange/red) were identified during their study (see Brodie et al. 1997). Although these forms were found to be externally dissimilar, they were published together under the name $D$. fumata because of their indistinguishable internal anatomy and apparent overlapping egg mass characteristics.

The current manuscript will thus provide (a) additional evidence for the continued separation of $D$. nigra and $D$. fumata, (b) clear evidence for the separation of the grey and black forms of $D$. fumata, and (c) recognition that $D$. fumata (black form) is a junior synonym of $D$. arborescens. Data from Rose (1985) and Brodie et al. (1997) are reassessed and combined with new data obtained from fresh observations of the colour pattern, morphology and larval features of living specimens. This is undertaken for the three species (and forms) discussed above, except for the orange form of $D$. fumata that was not found during fieldwork for the present manuscript in Spring 2003. As discussed by Brodie et al. (1997: 414-5) the black form of $D$. fumata is a synonym for $D$. arborescens Collingwood (1881) and we now follow their statement that "if the black form of $D$. fumata is clearly distinguished as a valid species we have no hesitation in using Collingwood's name for it". Two good colour photographs of $D$. arborescens are found in popular books (Willan and Coleman 1984 photograph 128 page 41; Wells and Bryce 1993 photograph 182 page 141) under the name $D$. nigra, and they both depict specimens from Western Australia.

Traditionally in opisthobranch taxonomy, as in 
other invertebrate groups, both external morphology and internal anatomy has been the primary basis used to separate species. However, several studies (e.g., Eckelbarger and Grassle, 1987, Calado and Urgorri, 2002) highlight the useful nature of information such as size and shape of eggs and larval characteristics to species resolution. The following study ensues that lead.

\section{MATERIALS AND METHODS}

Adult specimens of $D$. nigra (23 specimens), $D$. fumata [= D. fumata (grey form) of Brodie et al., 1997] (6 specimens) and $D$. arborescens $[=D$. fumata (black form) of Brodie et al., 1997] (7 specimens) were collected intertidally from two sites, Rowes Bay, Townsville $\left(146^{\circ} 50^{\prime}, 19^{\circ} 10^{\prime}\right)$ and Cockle Bay, Magnetic Island, Townsville $\left(146^{\circ} 48^{\prime}, 1^{\circ} 12^{\prime}\right)$, Queensland, Australia, between September and November 2003. Animals were transferred to the laboratory and kept in $2.6 \mathrm{~L}$ containers on a 4,500 L continuous-flow closed water system at $26-27^{\circ} \mathrm{C}$ with a photoperiod $13 \mathrm{~h}$ light/11h dark. Ad libitum feeding was provided with the sponge Tedania sp., collected from the same sites, attached to small boulders or pieces of dead coral. Nudibranchs were inspected daily and when spawning occurred, egg masses were detached from the substrata and transferred to isolated beakers with Millipore filtered seawater. Once hatched, larvae were raised at a concentration of 5 larvae $/ \mathrm{ml}$ and fed on a microalgal mixture of 1:1 Isochrysis sp. and Pavlova $\mathrm{sp}$. (about 5000 cells $/ \mathrm{ml}$ ). Whenever undivided zygotes were found in fresh laid spawn masses, a sample was taken to measure their average diameter. Measurements on ten different zygotes were taken using a high-powered microscope and calibrated stage micrometer. The same measurement procedures were undertaken for the larval shells during different periods of development. Additionally, observations on larval behaviour (> 10 for each species) were also recorded.

The thirty-six adult specimens used to produce larvae were compared and matched to the species and form descriptions of Brodie et al. (1997). In addition, one specimen of $D$. arborescens from Rowes Bay ( $60 \mathrm{~mm}$ live length) collected intertidally by John Collins on August $14^{\text {th }} 1994$ was examined by resin histology (see Wägele et al. 1999 and Brodie 2001 for details of the methodology used) to provide confirmation of reproductive system components. A voucher specimen of $D$. arborescens will be lodged in the Museum of Tropical Queensland (MTQ), Townsville. An additional specimen (QM MO18868) was lodged at MTQ, under the name $D$. fumata (black form), by Brodie et al. (1997).

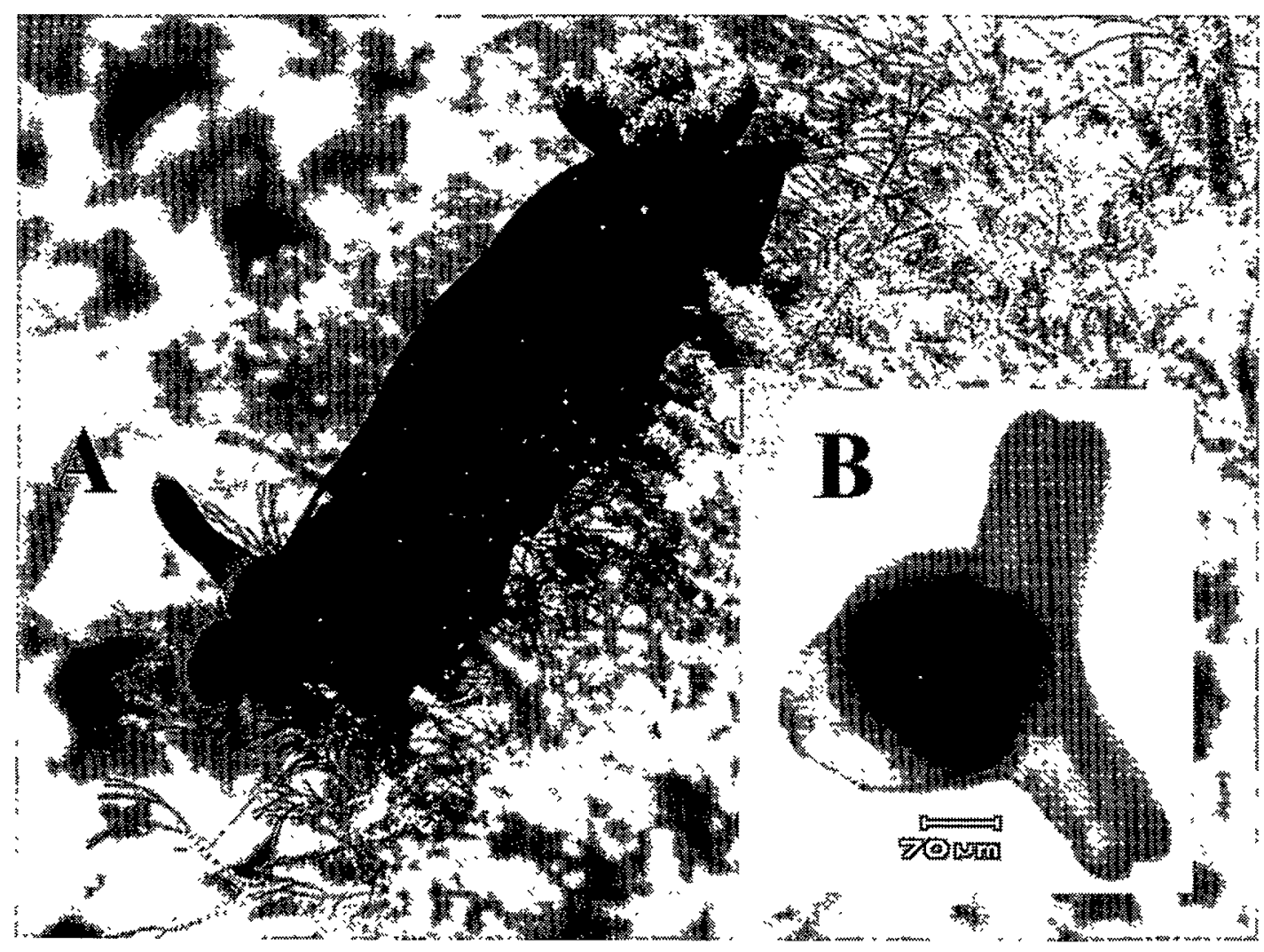

Figure 1 A, living specimen of D. arborescens showing the low body profile, elongate body, smooth notum with wavy margins and pale apices to gills. Note that the small pale dots on the notum are artefacts (grains of sediment), photograph by Clay Bryce; $B$, a living veliger larvae of $D$. arborescens. 


\section{RESULTS}

\section{Colour pattern and morphology}

All specimens examined conformed to the previous, species and form descriptions of Brodie et al. (1997) and these details plus the extensive associated synonymies will not be repeated here. However, it is useful to reiterate the confirmed external appearance of $D$. arborescens (that is consistent irrespective of size) and repeat several contrasting features of $D$. nigra because the two species can be so easily mistaken. Individuals of $D$. arborescens are uniformly black, have a low body profile, an elongate body and a smooth notum often with wavy margins (Figure 1A). The dorsum lacks white spots (note dots in Figure 1A are artefacts) or any other significant markings except for a marginal red border (rather than a submarginal band) to the notal edge. The black or dark grey gills always have pale apices and the gill plumes spreads outward in resting individuals. In contrast the individuals of $D$. nigra used in the current study, were more variable in colour with a red sub-marginal band to the notum sometimes but not always present and white spots to the notum predominately but not always present (see Brodie et al. 1997 Figures 1A and B). Additionally in living, non-stressed, resting individuals the individual gill plumes are cupped inwards.

\section{Reproductive system anatomy}

The histological analysis of the reproductive system of $D$. arborescens found a vestibular gland located close to the distal oviduct. This gland is embedded in the body wall. The vestibular gland was found to have the same unusual cellular structure as already well documented for other members of the genus.

\section{Spawn and egg size}

A comparison of spawn and egg size characteristics, as determined in the current study, is provided in Table 1. Dendrodoris nigra is by far the species with the smallest eggs $(74-81 \mu \mathrm{m})$, followed by $D$. fumata $(117 \mu \mathrm{m})$. Accordingly, $D$. arborescens, with bigger eggs (126-137 $\mu \mathrm{m})$, has the smallest number of eggs per mass ( $\sim 6,500$ eggs/ mass). The three species present a similar time to hatching (5-8 days) at the studied temperatures, but again they can be ranked by the size of the larval shell at hatching.

\section{Larval characteristics}

The larvae of $D$. arborescens (Figure 1B) have a densely pigmented, but still translucent, cup-like shell (Figure 2A), deprived of operculum. The pigmentation gives the shell a brownish tonality. The bilobed velum is very broad, about $260-280 \mu \mathrm{m}$ wide, and cannot be retracted into the shell. The larval shell is discarded by the veliger larvae about 6 days after hatching however at this stage individuals still maintain a planktonic behaviour and can be seen to ingest provided microalgae. Larvae of this species were kept alive in the laboratory for up to 30 days. Eye development was visible quite late in the larval development sequence but this could be an artefact, since the larva is very opaque.

In contrast to $D$. arborescens, both $D$. fumata and $D$. nigra have a transparent, spirally coiled, typical type 1 (sensu Thompson, 1961) larval shell (Figures 2B and $2 \mathrm{Cl}$ respectively) with an operculum. The velum of an individual larva can be totally retracted into the shell in both species. Veliger larvae of $D$. nigra hatch 4-5 days prior to eyespot development. When larvae were fed, microalgae were easily visible in the larval gut and considerable shell growth (135 to $269 \mu \mathrm{m}$ ) was observed in the 30 days they survived in the laboratory (Figure 2C2) (growth rate $=4.5 \mu \mathrm{m} /$ day). In comparison, veligers of $D$. fumata were larger than those of $D$. nigra at hatching and already had eyespots. Larvae of this species were also fed and kept alive for 30 days, however during this period no significant growth

Table 1 A comparison of the spawn, egg size and larval shell characteristics found among the three species of Dendrodoris examined in the current study.

\begin{tabular}{cccc}
\hline Species & D. arborescesns & D. fumata & D. nigra \\
\hline Uncleaved egg diameter range $(\mu \mathrm{m})$ & $126 \pm 4.6-137 \pm 4.7$ & $117 \pm 4.8$ & $74 \pm 2.8-81 \pm 1.7$ \\
(number of eggs) & $(\mathrm{n}=30)(\mathrm{n}=15)$ & $(\mathrm{n}=7)$ & $(\mathrm{n}=10)(\mathrm{n}=30)$ \\
(number of spawn masses) & $(3)$ & $(1)$ & $(8)$ \\
Estimated no. eggs $/$ mass & $6,528-7,296$ & 54,945 & $8,448-169,344$ \\
(number of spawn masses) & $(2)$ & $(1)$ & $(23)$ \\
Time to hatch in days $\left(26-27^{\circ} \mathrm{C}\right)$ & $6-7$ & $6-8$ & $5-7$ \\
(number of spawn masses) & $(3)$ & $(3)$ & $(6)$ \\
Early hatched larval shell length $(\mu \mathrm{m})$ & $151 \pm 8.4$ & $220 \pm 13.9$ & $135 \pm 6.0$ \\
(number of larvae) & $(6)$ & $(11)$ & $(13)$ \\
\hline
\end{tabular}


Table 2 A comparison of colour pattern, gill structure, egg mass details and larval characteristics recorded from previous studies in comparison to the current study.

\begin{tabular}{|c|c|c|c|c|c|}
\hline SPECIES & FEATURE & $\begin{array}{l}\text { Gohar and } \\
\text { Soliman } 1967\end{array}$ & Rose 1985 & Brodie et al. 1997 & CURRENT STUDY \\
\hline \multirow[t]{9}{*}{ D. arborescens } & Colour pattern & - & $\begin{array}{l}\text { As } D \text {. nigra Form } 2 \\
\text { jet black or } \\
\text { red-rimmed mantle }\end{array}$ & $\begin{array}{l}\text { As } D \text {. fumata (black form) } \\
\text { uniform black, no notal } \\
\text { markings except marginal red } \\
\text { border to mantle margin. } \\
\text { Gill apices pale. }\end{array}$ & $\begin{array}{l}\text { Uniform black, no notal markings except } \\
\text { marginal red border to mantle margin. } \\
\text { Gill apices pale. }\end{array}$ \\
\hline & $\begin{array}{l}\text { Reproductive } \\
\text { (vestibular gland) }\end{array}$ & - & not dissected or sectioned & Not seen & Present, embedded in body wall \\
\hline & Gill structure & - & not recorded & $\begin{array}{l}\text { Individual plumes spread } \\
\text { outwards in resting individual }\end{array}$ & $\begin{array}{l}\text { Individual plumes spread outwards } \\
\text { in resting individual }\end{array}$ \\
\hline & Larval shell features & - & $\begin{array}{l}\text { dark pigmentation on } \\
\text { shell, no operculum }\end{array}$ & - & $\begin{array}{l}\text { larval shell with brown pigment; } \\
\text { no whorl; no operculum }\end{array}$ \\
\hline & $\begin{array}{l}\text { Time for hatching (Days) } \\
\left.\text { [temperature }{ }^{\circ} \mathrm{C}\right]\end{array}$ & - & $9.0-9.6[22-23]$ & - & $6-7[26-27]$ \\
\hline & Shell length at hatching $(\mu \mathrm{m})$ & - & $\begin{array}{l}\text { jet black - } 153 \\
\text { red-rimmed - } 144\end{array}$ & - & $151(6)$ \\
\hline & Eggs per spawn mass & - & 67,584 (average) & $8,500-25,500(4)$ & $6,528-7,296(2)$ \\
\hline & Capsule size $(\mu \mathrm{m})$ & - & $\begin{array}{l}\text { jet black }-163 \\
\text { red-rimmed }-140\end{array}$ & $166.2-224.0(4)$ & - \\
\hline & Egg size $(\mu \mathrm{m})$ & - & $121-129$ & $133.6-159.0(3)$ & $126-137(3)$ \\
\hline \multirow[t]{3}{*}{$D \cdot$ fumata } & Colour pattern & adults - translucent grey & - & Translucent grey & Translucent grey \\
\hline & $\begin{array}{l}\text { Reproductive } \\
\text { (vestibular gland) }\end{array}$ & $\begin{array}{l}\text { Organ system dissected } \\
\text { but vg not seen }\end{array}$ & - & Not seen & $\begin{array}{l}\text { Present embedded in body wall, } \\
\text { see Brodie } 2001 .\end{array}$ \\
\hline & Gill Structure & $\begin{array}{l}\text { semi-circular collar } \\
\text { open posteriorly }\end{array}$ & - & $\begin{array}{l}\text { Individual plumes spread outwards } \\
\text { in resting individual }\end{array}$ & $\begin{array}{l}\text { Individual plumes spread outwards } \\
\text { in resting individual }\end{array}$ \\
\hline
\end{tabular}


Larval Shell features

Transparent smooth larval shell (Type B) and operculum

Time for hatching (Days) [temperature "C]

Shell length at hatching ( $\mu \mathrm{m})$

Eggs per spawn mass

Capsule Size $(\mu \mathrm{m})$

Egg size ( $\mu \mathrm{m})$

D. nigra

Colour pattern

Reproductive

(vestibular gland)

Gill structure

Larval shell features

Time for hatching (Days)

[temperature " $\mathrm{C}$ ]

Shell length at hatching $(\mu \mathrm{m})$

Eggs per spawn mass

Capsule size $(\mu \mathrm{m})$

Egg size $(\mu \mathrm{m})$
157

Larval shell transparent; with whorls and operculum

$6-8[26-27]$

$220(11)$

$54,945(1)$

$-$

$$
\begin{gathered}
11,000-122,500(9) \\
154.1-184.4(9) \\
125.2-150.9(6)
\end{gathered}
$$$$
110-135
$$

100 (average)$$
17(1)
$$

As D. nigra Form 1

white-speckled brown-black or grey

not dissected

or sectioned

not recorded

transparent larval shell

$9.0-9.6[22-23]$

114

$120,000-242,000$

121

75
Very variable -generally black or dark, often with white spots, sometimes with a red sub-marginal band to the notal edge. Gill plume uniformly dark in colour.

Present, annexed to distal oviduct

Gill plumes cupped inwards

Body black to dark grey, often with white spots, sometimes with a red sub-marginal band to

the notal edge. Gill plumes

uniformly dark in colour.

Present, annexed to distal oviduct

Gill plumes cupped inwards Larval shell transparent with whorls and operculum

$$
\text { 5-7 [26-27] }
$$

$8,448-169,344(23)$ 

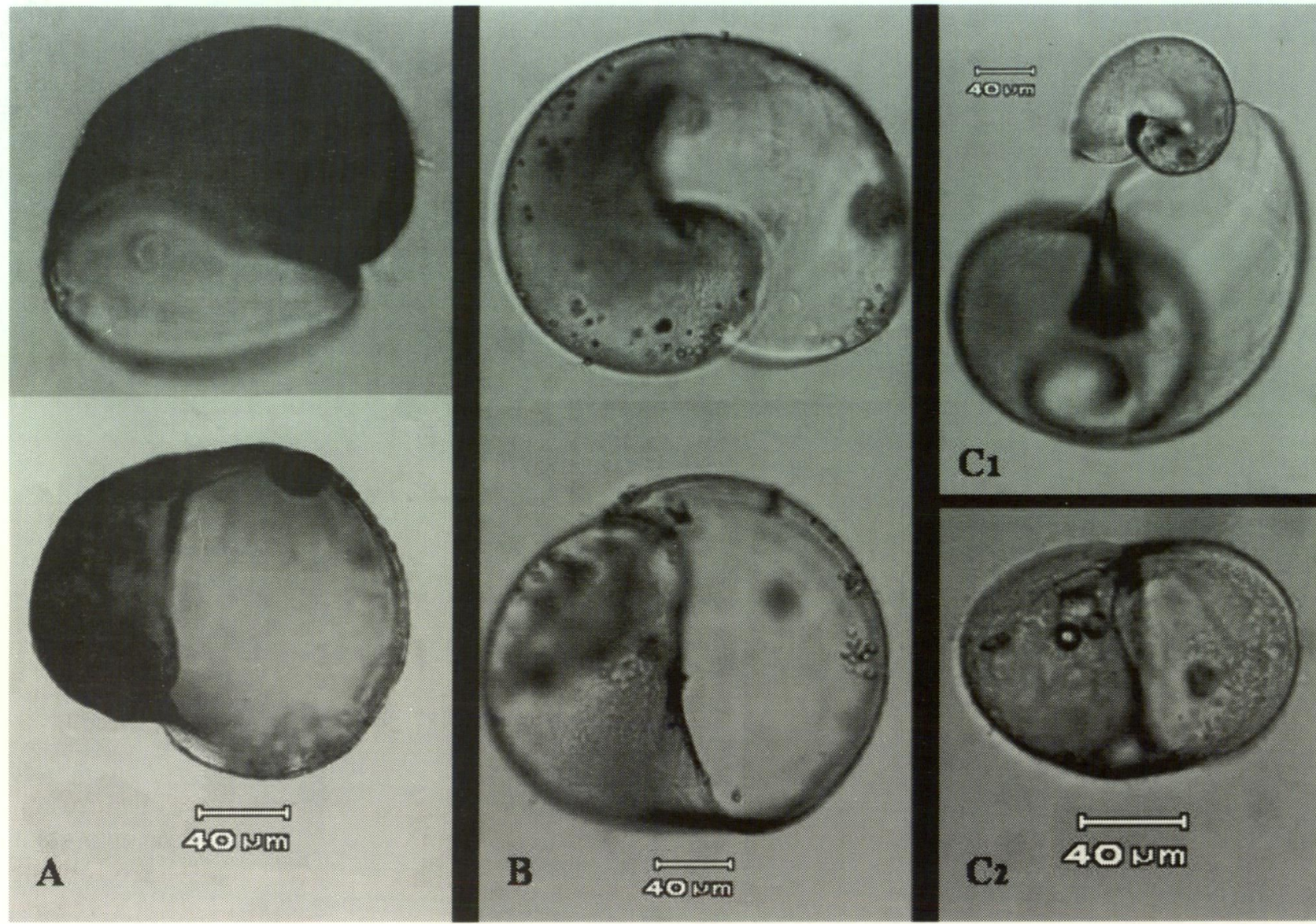

Figure 2 A, the pigmented larval shell of $D$. arborescens photographed from two different angles. B, the transparent larval shell of $D$. fumata photographed from two different angles. $C$, the transparent larval shell of $D$. nigra also photographed from two different angles plus also showing (in the top photograph) two different stages of development; $\mathrm{C} 1$ = the shell of a recently hatched veliger compared to the shell of a veliger fed for 30 days, $\mathrm{C} 2$ = the shell of a recently hatched veliger from a different angle. Note the different magnifications used between $\mathrm{C} 1$ and $\mathrm{C} 2$.

in larval shell length was observed even though microalgae were visible in the gut.

\section{DISCUSSION}

Contrary to the findings of Brodie et al. 1997, which did not employ histological analyses, a vestibular gland was found to be present in the reproductive system of $D$. arborescens. However, this gland was embedded in the body wall, which explains its previous lack of detection by dissection alone. The vestibular gland of $D$. arborescens was found to have the same unusual cellular structure as already well documented for $D$. nigra and $D$. fumata (grey form and orange/red form) by Wägele, et al. (1999, Figure 4A and B), Klussmann-Kolb and Brodie (1999, Figure 1A) and Brodie (2001: 102).

As also discussed by Brodie et al. (1997), under the name $D$. fumata (black form), adults of $D$. arborescens are easily confounded with $D$. nigra. Nevertheless, when one looks at the larval morphology, as already pointed out by Rose (1985), these two species are easily distinguishable (Table
2). Rose (1985) provides a detailed description of the larval development of what he called forms 1 and 2 of D. nigra. Form 2 is further divided into "red-rimmed mantle" and "jet-black" animals and we wonder why this author did not go the obvious step further of revalidating the specific name $D$. arborescens. All of the main features of spawn masses and larval characteristics presented by Rose (1985) match our results, except in respect to time to hatching and the fact that we did not find, and therefore did not investigate, any "jet-black" animals. A considerably longer hatching time for both forms is found in the work of Rose (1985) and this difference is certainly due to the lower temperature conditions found in New South Wales (central eastern Australia), which were also adopted in the laboratory $\left(22-23^{\circ} \mathrm{C}\right)$. Form 1 is the true $D$. nigra whereas form 2 should be attributed to $D$. arborescens. Nevertheless, both "red-rimmed mantle" and "jet-black" sub-forms have the same, very distinctive, larval shell, differing only in some meristic characters. Besides that, the larval data for form 2 "red-rimmed mantle" were obtained only 
from a single egg mass. Rose (1985) also refers to the resemblance of this unusual larval shell to that of the dorid Aegires punctilucens as described by Thiriot-Quievreux (1977). More recently, the same type of shell was found in Acgires albopunctatus by Goddard (2001). Goddard (2001) and Gibson (2003) also discuss the presence of this type of larval shell in the notaspideans, especially the lack of operculum. In addition, we are not aware of any other species that sheds its shell and then lives for so long as a shell-less larva.

Although limited, the data that we were able to obtain for D. fumata are in the same range of those presented by Gohar and Soliman (1967) and Brodie et al. (1997), the latter as D. fumata grey form. Like Brodie et al. (1997), we did not observe any opaqueness in the larval shell of D. fumata as previously documented for Red Sea individuals by Gohar and Soliman (1967). The larval shells of D. fumate and D. nigra were always transparent in the current study.

Based on external features, colour pattern, gill structure and larval characteristics, we conclude that this species is D. arborescens, whose type locality is Hanin Strait, in Formosa Strait, China, and which was previously not known to be found along the Australian coastline. Its recognition here raises the number of known members of Dendrodoris in Australia (see Brodie 2004) to thirteen and strongly reinforces the useful nature of larval biology to the resolution of confounded species complexes.

\section{ACKNOWLEDGEMENTS}

G.C. holds a grant from the Fundação para a Ciência e Teconologia, Portugal (BPD7133/2001). GB holds a grant (with $H$. Wägele) from the Australian Biological Resources Study (ABRS 202150). This manuscript is contribution No. 30 of the Marine Invertebrate Group at JCU and was presented as a poster at the opisthobranch symposium held during the World Congress of Malacology, Perth, July 2004. This work was undertaken under a permit granted by the Great Barrier Reef Marine Park Authority (G03/11769.1).

\section{REFERENCES}

Brodie, G.D. (2001) Some comparative histologicalaspects of the dendrodorid genera Doriopsilla and Dendrodorts (Opisthobranchia: Nudibranchia). Bollettino Malacologico 37: 99-104.

Brodie, G.D. (2004). Systematics of the molluscan nudibranch family Dendrodorididae (Opisthobranchia: Anthobranchia: Doridoidea) in Australia, and its phylogenetic relationships. foumal and Procedings of Royal Society of New South Wales 137 (parts 1 and 2).
Brodie, G.D., Willan, R.C. and Collins, J.D. (1997). Taxonomy and distribution of the Dentrotoris nigra and Dendrodoris fumata (Nudibranchia: Dendrodorididae) in the Indo-west Pacific Region. Journal of Molluscan Studics 63: 411-427.

Calado, G., and Urgorri, V. (2002). A new species of Calma Alder and Hancock, 1855 (Gastropoda: Nudibranchia) with a review of the genus. fournal of Molluscan Studie's 68: 311-317.

Cimino, G., De Rosa, S., De Stefano, S., Sodano, G. and Villani, G. (1983). Dorid nudibranch elaborates its own chemical defense. Science 219: 1237-1238.

Collingwood, C. (1881). On some new species of nudibranchiate Mollusca from the Eastern Seas. Transactions of the Linnaian Society of London, Zoology Series 2, 2: 123-140.

Edmunds, M. (1971). Opisthobranchiate Mollusca from Tanzania (Suborder: Doridacea). Zoological foumal of the Limnaean Socicty 50: 339-396.

Eckelbarger, K. J. and Grassle, J.P. (1987). Interspecific variation in genital spine, sperm, and larval morphology in six sibling species of Capitella. Bulletin of the Biological Socicty of Washington 7: 62-76.

Fontana, A., Ciavatta, M., Miyamoto, T, Spinella, A. and Cimino, G. (1999). Biosynthesis of drimane terpenoids in dorid molluscs: pivotal role of 7 deacetoxyolepupuane in two species of Dendrodoris nudibranchs. Tetrahedron 55: 5937-5946.

Gibson, G.D. (2003). Larval development and metamorphosis in Pleurobranchaea maculata, with a review of development in the Notaspidea (Opistobranchia). The Biological Bulletin 205: 121-132.

Goddard, J. (2001). The early veliger larvae of Aegires albopunctatus (Nudibranchia: Aegiridae), with morphological comparisons to members of the Notaspidea. The Veliger 44: 398-406.

Gohar, H.A.F. and Soliman, G.N. (1967). The biology and development of Dendrodoris (= Doridopsis) fumata (Rüppell and Leuckart) (Gastropoda, Nudibranchia). Publications of the Marine Biological Station, AlGhardaga, Red Sea 14: 31-54.

Karuso, P. (1987). Chemical Ecology of Nudibranchs. In Scheuer, P.J. (ed). Bioorganic Marine Chemistry Volume 1: 31-60. Springer-Verlag.

Klussmann-Kolb, A. and Brodie, G.D. (1999). Internal storage and production of symbiotic bacteria in the reproductive system of a tropical marine gastropod. Marine Biology 133: 443-447.

Rose, R.A. (1985). The spawn and embryonic development of colour variants of Dendredoris migra Stimpson (Mollusca: Nudibranchia). Journal Malacolosical Socity of Australia 7: 75-88.

Thiriot-Quievreux, C. (1977). Véligère planctotrophie du doridien Aegires punctilucens (D'Orbigny) (Mollusca: Nudibranchia: Notodorididae): description et metamorphose fournal of Experimental Marine Biolosy and Ecology 26: 177 190.

Thompson, T.E. (1961). The importance of the larval shell in the classification of the Sacoglossa and the Acoela (Gastropoda: Opisthobranchia). Proceedings of the Malacological Society of London 34: 233-238.

Thompson, T.E. (1975). Dorid nudibranchs from eastern 
Australia (Gastropoda: Opisthobranchia). Journal of Zoology 176: 477-517.

Valdés, Á. (2003). Preliminary molecular phylogeny of the radula-less dorids (Gastropoda: Opisthobranchia), based on 16S mtDNA sequence data. Journal of Molluscan Studies 69: 75-80.

Valdés, Á. and Gosliner, T. M. (1999). Phylogeny of the radula-less dorids (Mollusca, Nudibranchia), with the description of a new genus and a new family. Zoologica Script 28: 315-360.

Valdés, Á., Ortea, J., Ávila, C. and Ballesteros, M. (1996). Review of the genus Dendrodoris Ehrenbergh, 1831 (Gastropoda: Nudibranchia) in the Atlantic Ocean. Journal of Molluscan Studies 62: 1-31.

Wägele, H., Brodie, G. and Klussmann-Kolb, A. (1999). Histological investigations of Dendrodoris nigra (Gastropoda, Nudibranchia, Dendrodorididae). Molluscan Research 20: 79-94.
Wägele, H. and Willan, R.C. (2000). The phylogeny of the Nudibranchia. Zoological Journal Limnaean Society 130 83-181.

Wells, F. and Bryce, C. (1993). Sea slugs of Western Australia. Western Australian Museum, Perth.

Willan R.C. and Coleman, N. (1984). Nudibranchs of Australasia. Australasian Marine Photographic Index, Caringbah, Sydney.

Wollscheid-Lengeling, E. Boore, J., Brown, W. and Wägele, H. (2001). The phylogeny of Nudibranchia (Opisthobranchia, Gastropoda, Mollusca) reconstructed by three molecular markers. Organisms, Diversity and Evolution 1: 241-256.

Young, D. K. (1969). The functional morphology of the feeding apparatus of some Indo-west-Pacific dorid nudibranchs. Malacologia 9: 421-445. 